\title{
A presença de Dostoiévski no cinema de Woody Allen
}

\section{Paulo Mendonça \\ Universidade Federal Fluminense}

Resumo: No presente artigo, investigo de que maneira a obra cinematográfica de Woody Allen atualiza e discute algumas das principais temáticas presentes na literatura de Fiódor Dostoiévski. A partir do conceito de "cinema impuro" proposto por André Bazin, são analisados, principalmente, os filmes Match Point, Crimes $e$ Pecados e o romance Crime e Castigo.

Palavras-chave: Woody Allen, Dostoiévski, Cinema, Literatura

\begin{abstract}
In this article, I investigate how Woody Allen's cinematographic work updates and discusses some of the main themes present in Fiódor Dostoevsky's literature. Based on the concept of "impure cinema" proposed by André Bazin, I analyze mainly the films Match Point, Crimes and Misdemeanors and the novel Crime and Punishment.
\end{abstract}

Keywords: Woody Allen; Dostoevsky; Cinema; Literature 
Segundo André Bazin, o conceito de cinema impuro diz respeito às obras que não se preocupam em representar nas telas, de forma literal, o enredo original que lhes serviu como fonte primária. Nesse sentido,

É absurdo indignar-se com as degradações sofridas pelas obras-primas literárias na tela (...). Pois, por mais aproximativas que sejam as adaptações, elas não podem causar danos ao original junto à minoria que o conhece e aprecia; quanto aos ignorantes, das duas uma: ou se contentarão com o filme, que certamente vale por um outro, ou terão vontade de conhecer o modelo, o que é um ganho para a literatura, (Bazin 2018: 135)

Ora, se nos debruçarmos sobre algumas das melhores adaptações de obras literárias para o cinema, perceberemos que a "impureza" de que nos fala Bazin é quase uma regra. Provavelmente, isso se deve ao fato de que, por razões óbvias, um filme não comporta a prolixidade de que um romance, por exemplo, pode ser constituído. Como adaptar para o cinema Guerra e Paz sem ser necessariamente "impuro"? A versão realizada por King Vidor em 1956, a despeito de sua extensão inabitual para um filme (mais de três horas), jamais poderia reproduzir ipsis litteris o romance de Tolstói. O exemplo aqui é propositalmente exagerado, mas não precisaríamos de tanto. Mesmo as adaptações de obras menores em extensão comumente "editam" a narrativa romanesca a fim de que o enredo, na linguagem cinematográfica, torne-se realizável. 0 cinema impuro não é, pois, uma escolha, mas um imperativo quando tratamos de adaptações literárias. Em verdade, o conceito em si referese muito mais a uma tomada de consciência por parte do diretor que objetiva fazer a transposição de uma narrativa das páginas para as telas; a consciência de que a adaptação de um filme não pode operar com a mesma lógica da literatura é importante tanto para quem realiza, principalmente o diretor, quanto para quem consome o produto em seu derradeiro estágio, já nas salas do cinema.

No que concerne à extensa e irregular filmografia de Woody Allen, é preciso lembrar que o diretor americano jamais realizou um filme que objetivasse ser, literalmente, a adaptação de uma obra literária. Embora diversas de suas películas se reportem de modo direto a narrativas muito conhecidas, nenhuma é declaradamente uma adaptação. Por esse 
motivo, a concepção de impureza abordada por Bazin deve ser entendida aqui de modo particular. Não caberia afirmar, por exemplo, que o diretor de Match Point subverte nesse filme a narrativa de Crime e Castigo. Na medida em que não há intenção explícita de realizar-se adaptação, mas uma leitura do texto-fonte, devemos pensar no conceito de impureza como sinônimo de liberdade criativa.

Woody Allen quase sempre gozou de considerável liberdade quando da criação de suas obras. Quase sempre, pois sua estreia no cinema se deu com um filme nonsense, $O$ Que Há Tigresa? (What's up Tiger Lily? - 1966), em que o trabalho do diretor consistiu apenas em editar dois filmes "lado b" japoneses em cima dos quais se fez uma dublagem em inglês. 0 resultado é uma história intencionalmente sem sentido e confusa. Três anos depois, Woody Allen estrearia, de fato, como diretor de cinema em Um Assaltante Bem Trapalhão (Take the Money and Run - 1969), filme no qual se apresenta ao público também na frente das câmeras. Aqui, Allen encarna um papel que seria protótipo para praticamente todos as personagens que interpretaria em filmes subsequentes: um sujeito atrapalhado, neurótico e autodepreciativo. Em 1971 e 1972, Woody Allen começa a trazer as suas leituras para o cinema. Bananas (Bananas) e Tudo o Que Você Sempre Quis Saber sobre Sexo (Mas Tinha Medo de Perguntar) (Everything You Always Wanted to Know About Sex * But Were Afraid to Ask) são, respectivamente, releituras de Dom Quixote Americano (Richard Powell) e da obra homônima de David Reuben. Ainda não estamos diante de grandes filmes, mas é interessante notar como a relação entre literatura e cinema começa cedo na filmografia de Allen, que já declarou não ser um grande leitor: "I just got this in the mail one day. Some stranger in Brazil sent it and wrote, 'You'll like this'. Because it's a thin book, I read it. If it had been a thick book, I would have discarded it." [Eu recebi pelo correio um dia. Algum estranho do Brasil me mandou e escreveu 'você vai gostar disso'. Como é um livro fino, eu li. Se fosse grosso, eu teria descartado.] (Allen 2011). Ao explicar como conheceu Memórias Póstumas de Brás Cubas, o diretor reitera que o leu unicamente "because it's a thin book". Todavia, sabemos que é um erro primário acreditar cegamente em tudo o que diz um artista. Aliás, essa é a voz da qual mais devemos desconfiar! Com efeito, a desconfiança se justifica quando observamos o filme no qual Woody Allen começa a chamar atenção do 
público e da crítica como um promissor roteirista-diretor: A Última Noite de Boris Gruschenko (Love and Death - 1975). Aqui, além de Bergman e Chaplin, os diálogos e cenários escolhidos fazem referências evidentes à literatura russa, mais especialmente a Tolstói e Dostoiévski, o que ratifica o conhecimento do diretor norte-americano acerca de escritores que tanto o influenciariam posteriormente. Comenta o próprio Allen sobre o filme: "Escrevi uma história de crime e mistério, mas achei que não era muito boa, por isso coloquei-a de lado. Então tive um súbito desejo de fazer uma coisa russa com um tema levemente filosófico..." (apud Björkman 1995: 81).

Se A Última Noite de Boris Gruschenko despertou interesse da crítica pelo notável salto de qualidade que Woody Allen dera em relação aos filmes que escrevera e dirigira até então, é apenas com a obra seguinte, Noivo Neurótico, Noiva Nervosa (Annie Hall - 1977), que o diretor abandona de vez a comédia "pastelão" e se impõe como um grande artista capaz de deixar sua marca na história do cinema. Como percebe Neusa Barbosa,

Noivo Neurótico... é o que se pode chamar de divisor de águas no trabalho do diretor, sem medo de se estar aí recorrendo a um mero chavão. Ficam para trás as comédias ligeiras e qualquer cacoete dos tempos da comédia teatral. 0 alter ego cinematográfico encontra uma encarnação completamente definida e reconhecível de imediato. (Barbosa 2002: 56)

Acredito ser importante observar a evolução dos filmes de Woody Allen, desde $O$ Que Há Tigresa? até o ano de 1977, em que Noivo Neurótico... traz à luz um diretor mais maduro e reflexivo, comprometido em discutir o fazer artístico através da arte, sem deixar de lado a presença marcante de um humor inteligente que caracterizaria a maioria de seus filmes a partir de então. A respeito de Noivo Neurótico..., comenta o diretor nova-iorquino: “Queria dar um passo na direção de filmes mais realistas e profundos (...) ...passei a considerar Noivo Neurótico, Noiva Nervosa como o primeiro passo em direção à maturidade em certas maneiras de realizar filmes" (apud Björkman 1995: 85). Com esse filme, podemos dizer que Woody Allen passa a ser levado "a sério"; desde então, sua filmografia tem oscilado, a meu ver, positivamente. Apesar de algumas obras de qualidade discutível (o que me parece algo perfeitamente aceitável se considerarmos a quase obsessão do diretor em realizar um novo 
filme a cada ano), convém não perder de vista que depois de Noivo Neurótico... vieram à luz obras como Manhattan (Manhattan - 1979), Memórias (Stardust Memories - 1980), A Rosa Púrpura do Caíro (The Purple Rose of Cairo - 1985), Hannah e Suas Irmãs (Hannah and Her Sisters - 1986), Crimes e Pecados (Crimes and Misdemeanors - 1989) entre outros. Neste artigo, daremos um salto de algumas décadas a fim de observar, especialmente, a relação estreita entre os filmes Match Point, Crimes e Pecados e o mais conhecido romance de Fiódor Dostoiévski: Crime e Castigo.

Embora passe ao largo dos humilhados e ofendidos tão caros a Dostoiévski, Woody Allen retoma algumas importantes temáticas presentes na obra do escritor russo. Para o diretor, interessam os debates filosóficos: a questão da liberdade do homem em face de um mundo, possivelmente, sem Deus; a responsabilidade de nossas escolhas e a discussão sobre o destino e acaso. Aliás, esses são alguns dos temas presentes em Match Point. No filme, acompanhamos a história de um ambicioso instrutor de tênis, Chris Wilton (Jonathan Rhys Meyers), ex-jogador que se apaixona pela noiva de seu aluno particular, Nola Rice (Scarlett Johansson). Após se envolver com Nola e vê-la ameaçar sua vida confortável ao lado de Chloe (Emily Mortimer), Chris decide matar a amante a fim de manter o status quo de sua vida burguesa. Qualquer semelhança com Crimes e Pecados não é mera coincidência. Em ambas narrativas, o objetivo e os meios encontrados para alcançá-lo são os mesmos. Além disso, aquilo que se coloca como barreira no caminho dos protagonistas, suas amantes, também é idêntico. 0 enredo de Crime e Castigo, porém, é bastante diverso em aparência, daí devermos falar em leituras muito mais que em adaptações. É esse conceito que gostaria de defender no caso das obras que estudamos aqui.

A leitura cinematográfica pode ser, embora não o seja em sua essência, superior à adaptação. Enquanto esta objetiva recontar, com outra linguagem, uma história que foi escrita originalmente como romance ou drama, aquela não se prende às amarras do enredo original; não se preocupa com possíveis subversões e/ou impropriedades quanto à narrativa de que se alimenta: "subversão" é uma qualidade que lhe é própria. Não se trata, porém, de afirmar que as leituras cinematográficas são necessariamente superiores às adaptações (vide o caso da primorosa adaptação de Crime e Castigo, talvez a melhor, 
realizada por Lev Kulidzhanov), mas de compreender que a leitura é um ato de liberdade através do qual cada indivíduo constrói uma nova história baseada em suas experiências e vivência de mundo. Ainda que a adaptação também passe pela subjetividade de quem a realiza, portanto também é necessário falarmos aqui da leitura empreendida pelo sujeito, ela não tem o compromisso imediato com a liberdade, subordinando-se, quase sempre, ao texto-fonte que lhe originou. Caso não tenha apreciado o filme a que assistiu, um espectador de cinema menos experimentado não hesitará em apresentar sua justificativa: não gostou da obra por conta de sua infidelidade em relação à narrativa original, ao livro, cuja riqueza de detalhes lhe parecera muito mais interessante; as características psicológicas das personagens, muito mais desenvolvidas.

As obras de Woody Allen, porém, apresentam uma leitura particular de Dostoiévski, especialmente de Crime e Castigo, e fazem parte de um conjunto de filmes que podemos chamar de leituras cinematográficas. Match Point é, provavelmente, uma das leituras mais explícitas do diretor, no qual as referências saltam aos olhos daqueles que conhecem o romance/escritor a que se faz alusão. Mas seria possível "atualizar" as discussões que Dostoiévski apresenta em Crime e Castigo? Como fazê-lo tendo em vista épocas tão distantes? Para responder a essas perguntas, devemos lembrar que Dostoiévski é um escritor por excelência filosófico, preocupado em discutir questões que extrapolam o tempo-espaço, isto é, que dizem respeito aos seres humanos pretéritos e futuros. Em outras palavras, o romance dostoievskiano aborda temáticas que existiam muito antes da obra de Dostoiévski vir ao mundo, e que continuaram a existir após a sua morte. Dessa forma, é perfeitamente plausível que elas sejam rediscutidas por Woody Allen em pleno século XXI, o que faz parecer algo estranho falar em "atualização", uma vez que, em grande medida, as problemáticas permanecem inalteradas em sua essência, não obstante se revistam de diferentes configurações contemporâneas.

Por se tratar de leitura e não uma adaptação de Crime e Castigo, nossa análise acerca de Match Point deve ter como norte a discussão dos elementos intrínsecos que compõem os argumentos principais das narrativas, o que nos ajudará a compreender de maneira mais proveitosa o percurso quase trágico dos protagonistas. Senão, vejamos. Enquanto a vida de 
Raskólnikov se deteriora pouco a pouco a partir do crime cometido, a de Chris prospera no plano das aparências. Por outro lado, a redenção alcançada pela personagem de Dostoiévski é diametralmente oposta à angústia e culpa que acompanham Chris até a última cena de Match Point. Raskólnikov tem um motivo filosófico para cometer o crime; Chris, um motivo pragmático. Assim com Judah em Crimes e Pecados, o protagonista de Match Point precisa garantir a estabilização de sua vida social. 0 assassinato de Chris pode ser lido, pois, como uma metáfora, representativa das inúmeras concessões que fazemos em nossas vidas para preservarmos o conforto de uma existência supostamente feliz. Chris sustenta uma mentira, enquanto Raskólnikov prefere enfrentar a verdade e pagar o preço necessário por ela.

Importante lembrar que a concepção de mundo dos artistas determina, em alguma ou em grande medida, o caráter ideológico de suas obras, a despeito de essas possuírem sua independência quando não são produzidas com objetivos exclusivamente panfletários. Assim, é natural que em Dostoiévski, um cristão ortodoxo, o perdão e a redenção sejam apresentados ao leitor como uma saída possível, não de fuga, mas de enfrentamento do castigo que o sujeito deve suportar; de igual maneira, também é absolutamente trivial que nas obras do agnóstico Woody Allen os sujeitos terminem "bem", mas sufocados pela culpa, impossibilitados de vislumbrar um perdão divino que lhes possa servir como consolo ou redenção espiritual.

É verdade que as diferentes formações ideológicas de Dostoiévski e Woody Allen se fazem notar em suas obras. Entretanto, independentemente da religiosidade marcante nos romances do escritor russo, não podemos esquecer que Dostoiévski fora preso quando jovem por flertar com grupos revolucionários socialistas, que certamente não tinham grande apreço por quaisquer religiões. Posteriormente, Dostoiévski se tornaria um cristão ortodoxo, mas não são poucos os romances em que a existência de Deus é posta em xeque, em que a generosidade cristã se encontra ao lado da ambição mundana do homem e de sua sede pelo poder. Memórias do Subsolo e Os Demônios são exemplos imediatos de obras que lançam luz sobre essa dicotomia. Em Crime e Castigo, é possível percebê-la na figura do próprio protagonista. Raskólnikov é um jovem de inteligência singular, mas impressionado pelas teorias que eram debatidas na Rússia à época. Na condição de intelectual, ele elabora 
uma teoria segundo a qual aos homens extraordinários tudo é permitido. É para prová-la a si mesmo que assassina a velha usurária. Quando comete o assassinato, é lógico imaginarmos que Raskólnikov não cria em Deus. Após o ato, o martírio que o atormenta lhe conduz, gradativamente, a uma percepção diversa da existência divina. Sem dúvida, uma das cenas mais marcantes da obra é o momento em que Raskólnikov pede que Sônia, uma jovem prostituta, leia o trecho da Bíblia que trata da ressureição de Lázaro. Aqui, Dostoiévski reproduz literalmente o discurso bíblico, intercalando-o com as sensações experimentadas por Sônia enquanto esta faz a leitura; é quase uma espécie de "conversão" de Raskólnikov, que pouco antes afirmara: “...pode ser que Deus absolutamente não exista” (Dostoiévski 2012: 332). Ao trazer a história de Lázaro à narrativa, Dostoiévski destaca a ressureição como metáfora. Com isso, sugere-se que só a “morte” de Raskólnikov pode livrá-lo da tormenta que passou a experimentar a partir do assassinato de Aliena e sua irmã Lisavieta.

Match Point apresenta uma visão muito mais pessimista em relação à existência. Afinal, em nenhum momento a "ressureição" parece ser uma via possível para Chris. Assim como já ocorrera em Crimes e Pecados, Woody Allen se coloca novamente em um polo oposto ao de Dostoiévski. Para o diretor, o ser humano escolhe o caminho mais fácil, que mais lhe convém, o caminho que melhor atende às suas necessidades imediatas. Por essa razão, Judah e Chris, embora atormentados pelos crimes que cometeram, não se entregam, sequer cogitam fazê-lo. A concepção cristã conduz a narrativa dostoievskiana, enquanto a filosofia niilista parece respaldar as ações das personagens de Woody Allen. Recordemos, porém, que o fato de uma visão cristã de mundo estar por trás da narrativa em nada interfere na dinâmica perversa de uma personagem como Raskólnikov, cujas ideias flertam diretamente com uma visão niilista e, por consequência, contestadora da existência. Na verdade, em Dostoiévski o ser humano é decisivamente contraditório. E, embora Woody Allen também apresente a contradição humana em seus filmes, a diferença fundamental em relação ao escritor russo parece ser o resultado da "equação"; em outras palavras, a visão de mundo presente nos filmes de Woody Allen é, em última instância, uma visão notadamente negativa. Aqui, caberia nos perguntarmos qual das duas concepções seria a 
mais realista, isto é, a mais próxima daquilo que experimentamos em nossas vidas cotidianas. Contudo, a resposta a esta pergunta não poderia deixar de ser partidária, razão pela qual ambas podem estar corretas ou equivocadas, a depender dos valores e visão de mundo daqueles que leem as obras literárias de Dostoiévski e assistem aos filmes de Woody Allen.

O negativismo, realista ou não, presente em Match Point pode ser verificado em muitas obras de Woody Allen. Trata-se de um modo de enxergar o mundo característico da cinematografia do diretor. 0 debate sobre a existência ou não de um Deus responsável pelo destino dos homens é um exemplo insistente. A personagem que discute esse tema de maneira mais interessante é Mickey Sachs (interpretado pelo próprio Woody Allen) em Hannah e Suas Irmãs (Hannah and Her Sisters - 1986). Todavia, nem sempre é o negativismo que "triunfa". No filme, Sachs, um judeu de nascimento, procura em diversas religiões uma resposta satisfatória para a sua existência; quer acreditar em Deus para que a vida possa ter algum sentido: "Faço qualquer coisa [para acreditar em Deus]. Pinto até ovos de Páscoa. Preciso de provas. Se não acredito em Deus, acho que a vida não vale a pena" (Hannah... 1985). Todavia, nenhuma religião parece responder aos seus questionamentos. Para Sachs, a religião é uma espécie de "produto" criado pelo homem, o que é representado pela cena em que a personagem retira da sacola de compras objetos religiosos, pão e... maionese! A disposição das "mercadorias" sobre a mesa as coloca em pé de igualdade, ratificando a visão cética personagem. No ápice de seu conflito existencial, Sachs decide pôr termo a seus dias, pois acredita que essa seria a única maneira de se ver livre da angústia alimentada pela eterna dúvida a respeito da existência de Deus. Sachs fracassa em seu intento, sai à rua e entra em um cinema:

Entrei em um cinema. Nem sabia qual era o filme. Precisava de um tempo para pensar... botar o mundo em uma perspectiva racional. Subi para o balcão e me sentei. Já havia assistido àquele filme várias vezes desde a infância e sempre adorava. Comecei a prestar atenção e a me envolver no filme. Daí, comecei a pensar: "como pôde pensar em se matar? Que estupidez! Veja essas pessoas na tela. São engraçadas. E se o pior for verdade? Deus não existe e só se vive uma vez. Não quer viver essa experiência? Não é tão chato assim!". Pensei que deveria parar de procurar respostas que nunca 
encontraria e curtir a vida enquanto durasse. E o depois? Quem sabe? Talvez exista algo, ninguém sabe. "Talvez" é um fio muito fino para nos apoiarmos mas é o que temos. Então, relaxei e comecei a curtir o momento. (Hannah... 1985)

Trata-se de uma das cenas mais interessantes do filme e, provavelmente, uma das mais significativas da filmografia de Woody Allen. Aqui, a personagem encontra na arte o sentido da vida. Essa temática fora discutida por Woody Allen, sob perspectiva semelhante, em A Rosa Púrpura do Cairo, mas em Hannah e Suas Irmãs ela é literalmente verbalizada por Sachs, que se dá conta de que vale a pena viver por um único momento de alegria. A dúvida sobre a existência ou não de Deus passa a ser algo secundário diante da possibilidade de se experimentar o lado positivo da vida, nesse caso simbolizado pelo cinema. Portanto, o pessimismo tão presente nas obras de Woody Allen nem sempre se faz vencedor. Ainda que seja representado através do ceticismo de Sachs, em Hannah e Suas Irmãs temos um exemplo interessante de como Allen também pode ser, por vezes, uma espécie de "pessimista alegre".

Já observamos que em Match Point e Crime e Castigo é possível notar um percurso quase trágico das personagens, o que se relaciona diretamente às diferentes concepções de mundo, positivas, negativas e/ou realistas, que estão por trás das narrativas de Dostoiévski e Woody Allen. Para compreender melhor esse percurso, é necessário recorrermos a Aristóteles e, consequentemente, às suas concepções de tragédia. Embora investiguemos neste estudo um romance e um filme, gêneros muito distantes da época em que Aristóteles escreveu sua Poética, as postulações do filósofo grego também se mostram válidas para nossa análise, uma vez que elas se tornaram, ao longo do tempo, referências fundamentais para a compreensão das manifestações da arte em suas mais diversas representações e linguagens. É forçoso ressaltar, porém: não se trata de observar um romance ou um filme como se uma tragédia fosse, mas de neles perceber um percurso trágico. Parece-me que podemos verificar esse percurso tanto em Match Point quanto em Crime e Castigo, mesmo que haja uma diferença significativa no que diz respeito ao desfecho das narrativas, porquanto na obra de Dostoiévski o epílogo indica a redenção de Raskólnikov, ao passo que 
no filme de Allen o silêncio denota o vazio, o nada absoluto em que se transformou a vida de Chris.

Aristóteles afirma que um mito bem estruturado (entenda-se narrativa em um sentido amplo) deve ser

antes simples do que duplo, como alguns pretendem; que nele se não passe da infelicidade para a felicidade, mas, pelo contrário, da dita para a desdita; e não por malvadez, mas por algum erro de uma personagem, a qual, como dissemos, propenda para melhor do que para pior. (Aristóteles 2001: 212 grifos meus)

Em certo sentido, o que o filósofo grego descreve na passagem em destaque é uma característica que nos habituamos a encontrar nos grandes romances (sobretudo o romance burguês), gênero que mantém relação próxima com a tragédia. Ora, assim como nos dramas a que Aristóteles faz menção em sua obra (Édipo Rei por exemplo), nas narrativas romanescas a mudança de estado das personagens é um imperativo comparável apenas à necessidade de que tal mudança aponte para o "infortúnio", isto é, para uma espécie de "castigo". Como exemplo, poderíamos citar inúmeros romances das mais diversas nacionalidades literárias. Para ficarmos apenas em um bastante conhecido, recordemos a derradeira cena de $O$ Vermelho e o Negro, em que Mathilde de La Mole carrega, altiva, a cabeça de Julien Sorel, seu amante que fora guilhotinado por atentar contra a vida de Sra. de Rênal. Conquanto dramática, essa é uma das mais belas cenas da literatura francesa, e evidencia a capacidade da arte de transformar o trágico em belo. Por sua vez, as obras de Dostoiévski, especialmente alguns dos grandes romances de sua fase madura, contrariam parcialmente a concepção aristotélica. Afinal, a redenção de Raskólnikov parece apontar para algo muito próximo da felicidade, uma mudança positiva. De toda forma, é preciso lembrar que tais obras são exceção dentro daquilo que costumamos chamar de grandes obras da literatura universal. Um leitor minimamente experimentado reconhece que a concepção aristotélica é, de fato, predominante no gênero romance.

Em relação ao cinema, a presença do "infortúnio" na narrativa deve ser considerada com maior atenção. Nesse caso, estamos tratando de uma manifestação artística por trás da 
qual opera, quase sempre, uma indústria cujo maior interesse é que o filme alcance considerável sucesso de público; em outras palavras, uma obra cinematográfica não pode se dar ao luxo de não se preocupar com a rentabilidade financeira que ela pode/deve produzir após o lançamento. Por esse motivo, grande parte dos filmes norte-americanos, notadamente os hollywoodianos, caminham na contramão da concepção narrativa proposta por Aristóteles. Na medida em que objetiva ser uma arte muito mais "palatável" que a literatura, portanto muito mais fácil de ser consumida, o cinema (ou certo tipo de cinema) está atento àquilo que ambiciona seu espectador, motivo pelo qual é quase prosaica a presença do happy end. Por extensão, é a mesma lógica que condiciona as famosas novelas da televisão brasileira. Por maiores que sejam os dissabores experimentados pelas personagens, sabemos que no final todas serão recompensadas pelo destino, que deverá ser necessariamente venturoso.

A cinematografia de Woody Allen parece caminhar em cima de uma linha tênue em relação ao desfecho da vida das personagens e, por conseguinte, das narrativas. Diferentemente do caráter novelesco de muitas obras hollywoodianas, que forçosamente terminam "bem", nos filmes de Allen, quando há um desfecho positivo este se dá de maneira sutil e, portanto, mais próxima do que podemos chamar de realidade. É o caso de Meia-noite em Paris (Midnight in Paris - 2011), em que o escritor Gil Pender (Owen Wilson) desfaz o noivado e descobre nas ruas de Paris um improvável amor; já na cena final de Noivo Neurótico..., Alvy Singer (Woody Allen) reflete sobre o fim de sua relação com Annie (Diane Keaton), para concluir que os relacionamentos são "irracionais, loucos e absurdos". Contudo, Woody Allen também soube construir narrativas que se coadunam com aquilo que propõe Aristóteles: a trajetória da personagem é uma trajetória de ascensão e queda, e o desfecho, trágico ou perto disso. Em Match Point, Chris consegue tudo o que ambicionara material e socialmente, mas permanece até o último instante da narrativa atormentado pelo crime que cometera. Nesse sentido, seu percurso pode ser considerado verdadeiramente trágico. Em uma das cenas finais do filme, não parece ser um mero acaso a citação de Chris, que, ao ser confrontado pelas duas mulheres que assassinara, se justifica com as palavras de Sófocles: "Sófocles disse: 'jamais ter nascido pode ser a maior dádiva de todas'” (Match... 
2005). Possivelmente, jamais ter nascido é o que Édipo desejou ao saber que a mulher que tanto amava era sua mãe. Esse sentimento singular de tristeza e angústia também é experimentado por Chris. Afinal, se considerarmos que as personagens existem apenas em sua imaginação, é a si mesmo que ele revela o desejo reprimido de não existir.

Se a narrativa construída por Woody Allen em Match Point em muitos aspectos difere daquela que lemos em Crime e Castigo, isso apenas corrobora a ideia de que o diretor americano faz, de fato, uma leitura "impura" do romance nas telas do cinema. Mais que uma leitura de Dostoiévski por parte de Woody Allen, é interessante pensar Match Point como uma releitura que o diretor faz de si mesmo, uma vez que a temática do "crime perfeito" aparecera em Crimes e Pecados, filme que antecede Match Point em quase dezesseis anos. Não seria despropositado, pois, falarmos aqui de uma "impureza de ideias", haja vista que o diretor retoma, sob nova perspectiva, um tema que já lhe servira como argumento principal em outra obra. Se isso o fez, é provável que não tenha ficado de todo satisfeito com o resultado obtido quando do primeiro filme; é como se ainda houvesse algo a dizer. Com efeito, embora as narrativas de Crimes e Pecados e Match Point se assemelhem em diversos aspectos, sobretudo em relação à morte de amantes que atrapalham a vida confortável dos protagonistas Judah e Chris, há diferenças notáveis que merecem nossa atenção.

Em Crimes e Pecados, Judah representa os valores morais de uma sociedade conservadora no fim de uma era importante para o mundo. Mesmo que grande parte da filmografia de Woody Allen dê pouca atenção a aspectos históricos e políticos, concentrando-se, principalmente, na observação das relações entre os indivíduos, é impossível pensar quaisquer narrativas fora da História. Por isso, convém lembrar que Crimes e Pecados é lançado em 1989, o ano do "fim da história", em que o mundo viu a queda do muro de Berlim e, por extensão, o início do fim da Guerra Fria. Aparentemente, o american way of life, que se havia consolidado com a ajuda da dicotomia que então separava o mundo em duas metades, havia vencido. Entretanto, qual fora o custo dessa vitória? Aliás, esse "modo de ser", essencialmente individualista e meritocrático, seria justo e verdadeiro? Ao desnudar a intimidade de um aparente "vencedor" da sociedade capitalista estadunidense, representante fiel do estilo de vida americano, Crimes e Pecados revela que, 
amiúde, as práticas que condicionam e sustentam a "vitória" são escusas e mesquinhas. Ao vermos que Judah, apesar de seus crimes, permanece intocável, damo-nos conta da iniquidade existente à nossa volta. Assim, parece-me injusto considerar a filmografia de Woody Allen "alienada", mesmo que o próprio diretor assuma que pouco se interessa por discussões de caráter político em seus filmes: "Não quero fazer um filme político, porque sinto sempre que há melhores diretores do que eu para este trabalho. Estou mais interessando em outros problemas, questões psicológicas” (apud Barbosa 2002: 180). Em verdade, todo discurso é historicamente condicionado e, portanto, não pode deixar de ser, em última instância, político.

Em grande parte da filmografia de Woody Allen, é interessante notar como o diretor opera com uma lógica inversa daquela que serve de estrutura elementar às fábulas, nas quais a presença de uma moral edificante é um imperativo tão elementar quanto a necessidade de se punir o mal, visto que o bem deve ser ensinado e passado adiante. Em Crimes e Pecados, o mal triunfa, como é reconhecido pelo próprio Judah em uma das cenas finais, em que ele apresenta a Cliff Stern (Woody Allen) o "roteiro de um filme" que havia imaginado:

E após cometer esse ato horrível ele começa a ser perseguido por uma culpa profunda. Ecos de sua educação religiosa, que ele sempre rejeitou, começam a surgir. Ele ouve a voz do pai. Imagina que Deus vigia todos os seus passos. De repente, o universo não é mais vazio, ele é justo e tem uma moral. E ele a violou. Agora, ele está apavorado. Está no limiar de um colapso nervoso, perto de confessar tudo para a polícia. Então, um dia, ele acorda, o sol está brilhando e sua família está a seu redor. Misteriosamente, a crise desapareceu. Ele leva a família para a Europa, e descobre, com o tempo, que não foi castigado. Ao contrário, prospera. 0 crime é atribuído a outro, um vagabundo que já matou outras pessoas. Um a mais não importa. Agora, ele está livre. Sua vida volta completamente ao normal, ao seu mundo de riquezas e privilégios (Crimes... 1989).

Nessa cena, Judah confessa como se libertou da culpa pelo crime que encomendara. Aqui, a única moral é a completa ausência de moral. A verdadeira face do american way of life é revelada. Para se alcançar o sucesso nessa sociedade, pode-se infringir quaisquer 
regras, o que faz parte do jogo de aparências. Naturalmente, essa "infração" só é permitida aos "privilegiados", aos homens extraordinários, àqueles a quem "tudo é permitido".

A despeito da semelhança temática, Crimes e Pecados e Match Point se distinguem, e esta é uma diferença fundamental, pelo fato de apresentarem protagonistas em situações muito distintas. Chris não é um rico e bem-sucedido profissional, mas um irlandês, exjogador de tênis, que tenta ganhar a vida em outro país, uma nação que também adotou, em grande medida, o estilo de vida americano como norte principal. Se em Crimes e Pecados vemos o que Judah precisa fazer para preservar a sua vida privilegiada, em Match Point somos testemunhas do processo de ascensão do indivíduo que escolheu "vencer" a qualquer preço. Por essa razão, Match Point é uma narrativa ainda mais crítica a uma fórmula de felicidade que, parece, ganhou força desde as primeiras décadas do século passado. Para alcançá-la e vivenciá-la, o indivíduo está disposto a toda sorte de concessões, mesmo que elas entrem em conflito com aquilo que ele aprendera como moral universal.

Se a ambição e o desejo de pertencer à alta sociedade unem as personagens de Match Point e Crimes e Pecados, Chris e Raskólnikov se assemelham por sua juventude e origem humilde. No filme de 2005, pois, estamos diante de um protagonista muito mais próximo do "modelo" que Woody Allen encontrou no romance de Dostoiévski. Aqui, podemos retomar a discussão das adaptações cinematográficas ou, no caso das obras que investigamos, das leituras que uma obra fílmica pode realizar de uma narrativa em prosa. Além das semelhanças e diferenças entre as narrativas no que diz respeito ao tema de que tratam, o que temos visto até o momento, também é possível observar as aproximações e distanciamentos de caráter estrutural entre as obras em questão.

Em seu livro de ensaios $O$ Romancista Ingênuo e Sentimental, o escritor turco Orhan Pamuk apresenta alguns dos principais aspectos do romance e investiga as possibilidades técnico-discursivas exclusivas do gênero; em outras palavras, Pamuk discorre sobre o que o romance diz e a maneira particular como o faz. Para o autor, o romance é, de fato, o mais bem-acabado dos gêneros literários: “Um romance é uma segunda vida” (Pamuk 2011: 9). Tão importante quanto aquilo que é dito em um romance, é seu modus operandi. 
Compreender esse processo é fundamental para, em um momento posterior, esclarecermos cada vez mais o modo de construção da narrativa cinematográfica. Afinal,

O fato é que praticamente não existe um procedimento narrativo e visual descrito nos manuais de cinema ou nas histórias do filme que não tenha sido programado e utilizado pelos romancistas muito antes do surgimento do primeiro metro de película. (Miterrand 2014: 14)

Como afirma Miterrand, a despeito das inovações singulares que o cinema logrou à arte moderna, um filme bebe diretamente das fontes literárias, mais particularmente do romance. Daí a importância de se compreender minimamente a estruturação da narrativa romanesca, a "segunda vida" à qual somos apresentados ao folhear as primeiras páginas de um livro. De fato, muitos são os procedimentos técnicos que a narrativa cinematográfica toma emprestados do romance. Particularmente em relação ao romance dostoievskiano, porém, é importante lembrar o quanto a sua narrativa paga tributo a uma outra manifestação artística, muito anterior ao cinema e ao romance: o teatro. Não são poucos os estudiosos que o perceberam. Em seu Problemas da Poética de Dostoiévski, Bakhtin dedica uma seção ao estudo do diálogo na obra romanesca do autor de Memórias do Subsolo. Para o crítico russo, "nos romances de Dostoiévski tudo se reduz ao diálogo (...) Tudo é meio, o diálogo é o fim" (Bakhtin 2013: 293); por seu turno, B. Griftsov afirmava, décadas atrás, que "hoje, a ideia de que Dostoiévski, mesmo contra a sua vontade estética, tornou-se um profundo dramaturgo, dificilmente pode parecer a alguém nova e ousada". (apud Vássina 2008: 58). A dramaturgia presente na literatura de Dostoiévski certamente mereceria um estudo exclusivo. Aqui, a menção se deve ao fato de que essa característica marcante nos romances dostoievskianos os aproxima ainda mais de uma narrativa cinematográfica, que, em linhas muito gerais, opera com uma lógica que põe em primeiro plano o diálogo entre as personagens; ou entre as personagens e o mundo à sua volta, isto é, a autoconsciência que elas externalizam através de um discurso que está, em última instância, direcionado ao espectador.

Assim como o cinema se apropria das técnicas narrativas empregadas em um 
romance, assim também o romance, após a difusão do cinema no século passado, passou a apropriar-se de técnicas que, à primeira vista, foram criadas pelos cineastas. Ora, tal percepção, segundo Bazin em texto da década de 1950, é um lugar comum: "Se a crítica deplora frequentemente os empréstimos que o cinema faz à literatura, a existência da influência inversa é geralmente tida tanto por legítima quanto por evidente" (Bazin 2018: 130). Contemporaneamente, seria ainda mais trivial notar essa relação de empréstimo entre literatura e cinema, muito embora nem sempre as tentativas de inovação narrativa se traduzam em obras de notável qualidade estética. Todavia, é claro que, no caso de nosso estudo, não é possível, por razões temporais óbvias, falar em empréstimo da literatura dostoievskiana em relação ao cinema. Teremos sempre de caminhar no sentido inverso e observar os possíveis empréstimos entre romance e cinema, mas sempre tendo como ponto de partida o primeiro.

Um dos empréstimos mais evidentes que o cinema toma em relação ao romance é a presença de um narrador, responsável por apresentar a história para além dos diálogos entre as personagens. Também encontramos esse recurso, mas de modo diverso, no texto teatral. As rubricas (ou didascálias) servem como espécie de direcionamento da peça; elas revelam como o dramaturgo gostaria que o diretor e os atores montassem/interpretassem determinada cena. No romance ou em um filme, é possível integrar os comentários do narrador, onisciente ou não, ao enredo. Trata-se de um recurso prosaico em uma narrativa de terceira pessoa, mas que foi incorporado por muitos cineastas em filmes célebres: Crepúsculo dos Deuses (1950), Taxi Driver (1976), Apocalipse Now (1979), Cassino (1995), Trainspotting (1996), Clube da Luta (1999) e O Grande Lebowsky (1998) são alguns exemplos interessantes. Nesses filmes, as observações feitas pelos narradores podem originar-se de uma das personagens ou mesmo de um narrador onisciente responsável por "apresentar" a história ao espectador: a voice over, se quisermos utilizar uma linguagem cinematográfica. Não são poucos os filmes de Woody Allen que adotam esse recurso. Normalmente, são as próprias personagens que tecem considerações a respeito de um tema central na narrativa. Em Match Point, é de grande importância a cena inicial em que nos é apresentada uma metáfora acerca da vida: 
O homem que disse "prefiro ter sorte a ser bom" entendeu o significado da vida. As pessoas temem ver como grande parte da vida depende da sorte. É assustador pensar como boa parte dela foge do nosso controle. Há momentos em que a bola bate no topo da rede e, por um segundo, ela pode ir para o outro lado ou voltar. Com sorte, ela cai do outro lado e você ganha. Ou talvez não caia e você perca. (Match... 2005)

Enquanto essa voz, ainda desconhecida do espectador, apresenta sua visão de mundo, que imputa ao acaso a responsabilidade por grande parte de nossa existência, observamos o vaivém de uma bola de tênis em frente à rede. Nesse caso, estamos diante de uma particularidade que é própria do cinema: a possibilidade de narrar e ilustrar essa narração concomitantemente, o que, por óbvio, não é possível no romance tradicional. No cinema, o recurso do voice over é comumente associado à "preguiça" ou mesmo incompetência por parte de um diretor incapaz de contar uma história "apenas" através dos diálogos e imagens. Tratar-se-ia de uma "muleta" que transformaria o filme em uma mera transposição de texto às telas. Essa crítica parece ressoar, sobretudo, em direção às adaptações cinematográficas de contos ou romances. De fato, é compreensível que o diretor responsável por uma adaptação se sinta instigado a reproduzir, parcial ou literalmente, trechos do texto original que lhe serve de fonte primária para a realização do filme, e que para isso se valha do recurso voice over. Quando tal é utilizado de maneira despropositada, o resultado pode realmente soar artificial. Nos filmes de Woody Allen, porém, há uma intencionalidade por trás desse recurso notadamente literário. Afinal, sua filmografia é por excelência literária. Dessa forma, o que poderia parecer a outros diretores um "insulto", a comparação da estrutura de um filme à de um romance, para Woody Allen é apenas uma constatação óbvia de algo que é intrínseco às suas obras. Em Vicky Cristina Barcelona (2008), conhecemos boa parte da vida das personagens através da voz de um narrador; aqui temos, provavelmente, o filme de Woody Allen em que o uso do voice over é um recurso essencial, sem o que a história talvez não pudesse existir como a conhecemos.

Ainda sobre o trecho de Match Point em destaque acima, resta uma particularidade interessante que merece ser observada. Não obstante o filme nos apresente a história de 
Chris de maneira indireta, isto é, em "terceira pessoa", tal como o fazem os romances cujo narrador é uma espécie de Deus que a tudo vê e a todos observa, é a voz da própria personagem quem transmite um dos argumentos centrais que servirá como norte para a narrativa de sua vida que passamos a acompanhar. Sem dúvida, trata-se de um aperfeiçoamento do recurso do narrador literário, ou melhor, uma adaptação dele. Assim, cria-se um expediente singular no cinema. Em Beleza Americana (1999), filme dirigido por Sam Mendes e escrito por Alan Ball, o recurso do voice over também é utilizado de maneira original na cena de abertura. Através da voz de Lester Burnham (Kevin Spacey), sabemos que ele estará morto em menos de um ano. No entanto, assim como ocorre em Match Point, não é a personagem quem narra a história; tal qual uma peça de teatro, não há qualquer narrador aparente.

Outra característica própria dos romances que posteriormente seria adaptada pelo cinema é a decupagem da narrativa, que se relaciona intimamente ao modo pelo qual o gênero se consolidou durante o século XIX. Grande parte das obras que hoje lemos de uma só vez eram publicadas em revistas, periódicos ou nos chamados folhetins. Por isso, tornava-se imperativo que o escritor soubesse "repartir" sua história, de tal modo que o leitor fosse sempre alimentado pelo desejo de ler sua continuação. Crime e Castigo, por exemplo, foi publicado pela primeira vez em capítulos, na revista Mensageiro Russo (Rússki Véstnik). No cinema, a decupagem de cenas é fundamental para conferir o ritmo desejado pelo diretor à narrativa. Crimes e Pecados é um exemplo de filme no qual a escolha do que se vai contar e quando fazê-lo ganha amplas dimensões. Enquanto espectadores, somos apresentados a duas histórias paralelas, a dois protagonistas que, aparentemente, nada têm a ver um com o outro. Como já observamos, apenas ao final ambos vão, por mero acaso, se encontrar. Em um filme que opera com esse tipo de lógica narrativa, há que se observar se a sequência de cenas que o compõe está de acordo com a relevância das personagens no enredo original. No caso de Crimes e Pecados, os protagonistas têm igual importância para as narrativas de suas vidas e, por isso, devem adquirir o mesmo protagonismo. Diferentemente de grande parte dos romances, porém, é raro que haja algum tipo de intervalo entre "capítulos" (cenas) em um filme. Entretanto, para contrariar essa lógica e, 
uma vez mais, deixar clara a sua aproximação com a literatura, no cinema de Woody Allen é possível encontrar filmes cuja divisão em muito se assemelha à de um romance. 0 exemplo mais conhecido é, provavelmente, Hannah e Suas Irmãs, dividido em cinco capítulos. Em Crimes e Pecados, a passagem da narrativa dramática, que relata a vida de Judah, à tragicômica narrativa de Cliff Stearn é feita de modo abrupto. Exceção é a primeira aparição de Stearn, antecedida pela briga de Judah e sua amante. Entre as duas cenas, vemos uma terceira, transitória, a cena de um filme na qual um casal discute à semelhança de Judah e Dolores.

Para concluir, é importante lembrar que a relação estreita entre cinema e literatura pode se dar tanto no âmbito das estruturas composicionais, em que um filme se apropria de técnicas utilizadas, por exemplo, em um romance, quanto no âmbito temático, em que uma adaptação ambiciona realizar uma leitura, parcial ou não, de uma obra que fora construída sob alicerces aparentemente distintos. Em todos os casos, o fato é que os empréstimos, que ocorrem de ambos os lados, são positivos e ajudam a enriquecer o diálogo entre as artes. Principalmente no que diz respeito às chamadas adaptações, a história do cinema até o presente parece ter evidenciado que Bazin tinha razão ao defender a impureza cinematográfica. No cinema de Woody Allen, impuro por excelência, a presença da literatura pode ser observada sob dois ângulos distintos. Inicialmente, podemos analisar de que maneira as temáticas discutidas por grandes escritores como Dostoiévski são relidas pelo diretor em suas obras - o que fizemos modestamente neste texto. Além disso, acredito que seria interessante observar com atenção como a literatura de per si é uma questão recorrente/insistente nos filmes do diretor norte-americano. Afinal, o fato de filmes como Meia-noite em Paris ou Desconstruindo Harry terem como protagonistas escritores frustrados em busca de uma perdida inspiração não parece ser um mero acaso. A existência desses sujeitos demonstra, uma vez mais, a aproximação que Woody Allen sempre buscou entre o cinema e a literatura. 


\section{Bibliografia}

Allen, Woody (2011), "Woody Allen's top five books", <https://www.theguardian.com/books/2011/may/06/woody-allen-top-five-books> (último acesso em 10/06/2019).

Bakhtin, Mikhail (2013). Problemas da Poética de Dostoiévski, tradução de Paulo Bezerra, Rio de Janeiro, Forense Universitária.

Barbosa, Neusa (2002), Woody Allen, São Paulo, Editora Papagaio.

Bazin, André (2018), O Que É Cinema?, tradução de Eloisa Araújo Ribeiro, São Paulo, Ubu Editora.

Björkman, Stig (1995), Woody Allen por Woody Allen, tradução de Eduardo Vivácqua, São Paulo, Nórdica.

Crimes e Pecados. Direção: Woody Allen. EUA: Jack Rollins \& Charles H. Joffe Productions, 1989. 1 DVD (104 min.), son., col., legendado.

Dostoiévski, Fiódor (2009), Crime e Castigo, tradução de Paulo Bezerra, São Paulo, Editora 34.

Hannah e Suas Irmãs. Direção: Woody Allen. EUA: Jack Rollins \& Charles H. Joffe Productions, 1986. 1 DVD (107 min.), son., col., legendado.

Match Point. Direção: Woody Allen. EUA: BBC Films, Thema Production, 2005. 1 DVD (124 min.), son., col., legendado.

Mitterand, Henri (2014), 100 filmes. Da Literatura para o Cinema, tradução de Clóvis Marques, Rio de Janeiro, BestSeller.

Pamuk, Orhan (2011), O Romancista Ingênuo e Sentimental, tradução de Hildegard Feist, São Paulo, Companhia das Letras. 
Paulo Mendonça

Vássina, Elena (2008), "A poética do drama na prosa de Dostoiévski", In Dostoiévski. Caderno de Literatura e Cultura Russa, São Paulo, Ateliê Editorial, 53-63.

Paulo Mendonça é doutorando em Estudos de Literatura (Literatura Comparada) pela Universidade Federal Fluminense; mestre em Estudos de Literatura (Literatura Brasileira e Teorias da Literatura) e graduado em Letras (Port. / Literaturas e Port./Francês) pela mesma instituição. Em 2015-2016, contemplado com a Bolsa de Excelência Acadêmica da UFF, estudou Língua Francesa e Literaturas Francófonas na Université de Sherbrooke (Québec - Canadá). Atualmente, atua como professor de Língua Francesa na Educação Básica. Membro do grupo de pesquisa “Literatura e Dissonâncias” (UFF). 